Article

\title{
Hydrogeological Changes along a Fault Zone Caused by Earthquakes in the Moncayo Massif (Iberian Chain, Spain)
}

\author{
Eugenio Sanz ${ }^{1}$, Ignacio Menéndez Pidal ${ }^{1, *(\mathbb{D} \text {, José Ignacio Escavy }}{ }^{1}$ and \\ Joaquin Sanz de Ojeda ${ }^{2}$ \\ 1 Laboratorio de Geología, Departamento de Ingeniería y Morfología del Terreno, Universidad Politécnica de \\ Madrid, 28040 Madrid, Spain; eugenio.sanz@upm.es (E.S.); ji.escavy@upm.es (J.I.E.) \\ 2 Escuela Técnica Superior de Ingenieros de Minas y Energía, Universidad Politécnica de Madrid, \\ 28003 Madrid, Spain; joaquin.sanzdeojed@alumnos.upm.es \\ * Correspondence: ignacio.menendezpidal@upm.es
}

Received: 26 September 2020; Accepted: 27 October 2020; Published: 30 October 2020

check for updates

\begin{abstract}
The response of springs to earthquakes in the zone of moderate seismicity associated with the fault under study (the Talamantes-Castilruiz fault, Soria, Spain) always leads to a flow decrease regardless of the magnitude of the earthquake and the distance from the epicenter. The sensitivity of the springs is explained by the different degrees of the confinement of their aquifers. The semi-confined aquifer of the Vozmediano spring $(1100 \mathrm{~L} / \mathrm{s})$ experiences short post-seismic events with a variable decrease in flow and an increase in turbidity, depending on the intensity of the earthquakes felt at the site (Intensity). These changes are likely due to elastic deformation and an increased permeability in their aquifers. This spring is an example of how previous (historical) earthquakes can break the aquifer through the fault causing horizontal movements of the groundwater and displacing the discharge point to a different fracture site located six kilometers from the initial point.
\end{abstract}

Keywords: earthquakes; paleohydrogeology; spring discharge decrease

\section{Introduction and Objectives}

Earthquake-induced changes in spring flows and groundwater levels are widely documented [1-7]. Several mechanisms have been proposed to explain these changes after earthquakes including changes in aquifer parameters (permeability or storativity) through the clogging/unclogging of temporary barriers, elastic deformation, rupture of the aquifer, permeability enhancement, coseismic consolidation/liquefaction of sediments, etc. [7]. Seismic activity can also change the character of confined aquifers into semi-confined [8]. However, the number of cases studied has been limited and controversies about these mechanisms continue [9]. Most of the studies on this topic refer to earthquakes with magnitudes greater than $6[10,11]$, while few address the co- and post-seismic responses to earthquakes with small and moderate magnitudes [12]. Moreover, few studies deal with the response of a single water point to multiple earthquakes [13].

The main objective of this contribution is to study the behavior of springs in an area of fault-related moderate seismicity and, particularly, the response of the flow of a single spring to several earthquakes of different magnitudes and distances including those generated within the host fault. The possibility is also raised that the seismic activity associated with a fault may contribute, as a triggering cause, to breaking the top of a semi-confined aquifer and substantially modifying the location of the discharge point of a major aquifer. 


\section{Study Area}

The study area is located in the Moncayo Massif $(2315 \mathrm{~m})$ in the northern part of the Iberian Mountain Range (Spain). This cordillera has moderate seismicity; however, to the northwest of the Moncayo mountain there is an area with even greater seismic activity. This more active area is located in the marine Jurassic and Weald facies of the Cameros basin, which are areas associated with the NW-SE directional faults that limit the northern side of this mountain range with the Cenozoic Ebro basin. Small and medium magnitude earthquakes are relatively frequent in this area such as the Cerbón earthquake of 16 January 1906 (Mw 5) [14] and the earthquake of Aguilar del Río Alhama (also called the Magaña earthquake) dated 3 September 1961 (Mw 5.8) (Global Seismic Hazard Assessment Program, GSHAP catalog) (Figure 1). These earthquakes and a few other recent ones are associated with the $>60 \mathrm{~km}$ long Talamantes-Castilruiz fault (Figure 1). Moreover, in the central sector of the Talamantes-Castilruiz fault lies an area with neotectonic activity that causes the local subsidence of the calcareous Miocene and the formation of a small quaternary basin (Figure 1).

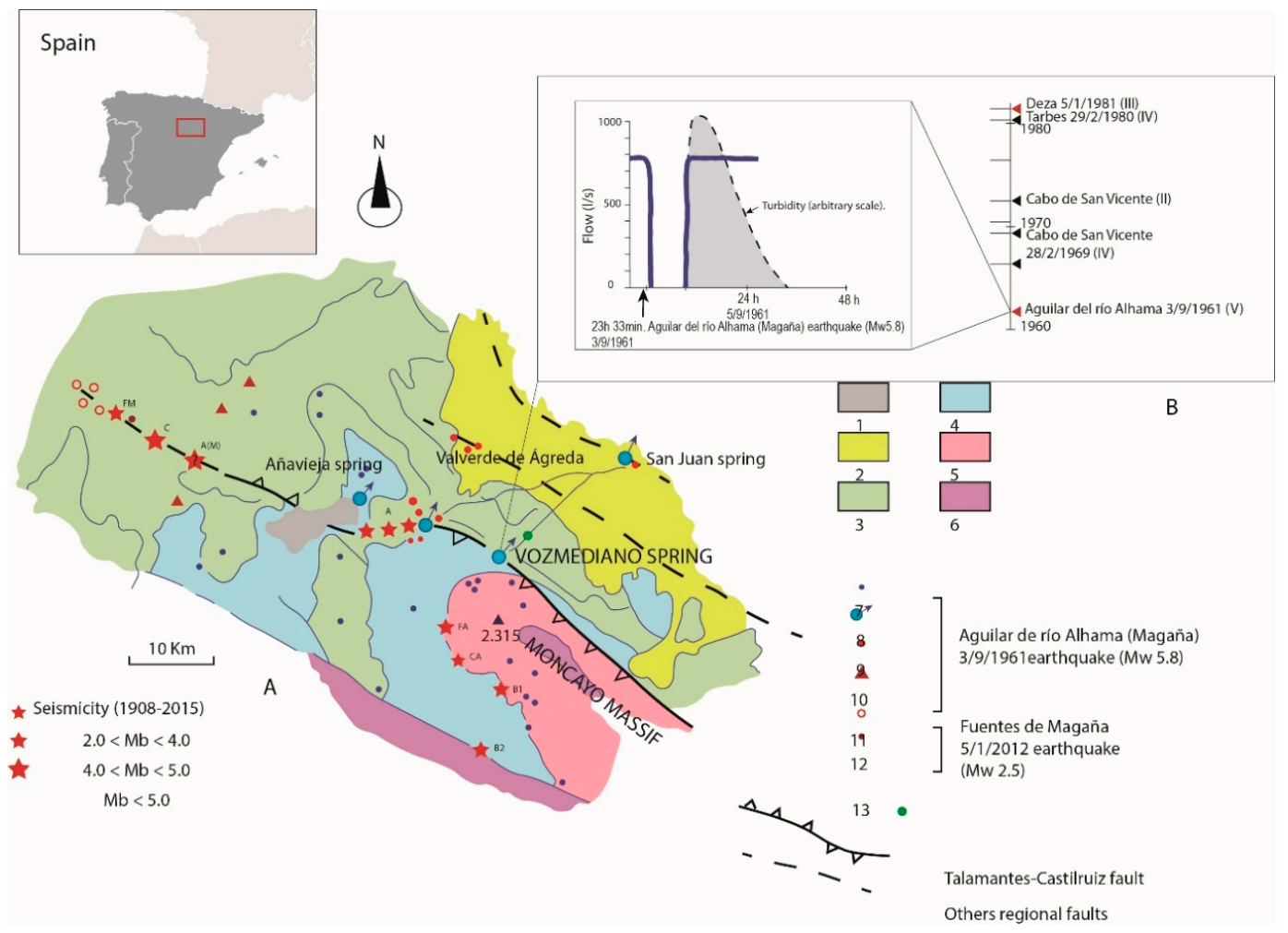

Figure 1. Geological setting of the study area. (A) Geology: 1. Recent tectonic activity in the quaternary Añavieja basin, 2. Neogene molasses, 3. weald facies, 4. marine Jurassic, 5. Triassic (Buntsandstein facies) and 6. Hercynian basement. Changes in the spring discharge after earthquakes: 7. Spring alterations during earthquakes, 8. large springs, 9 and 12. persistent spring discharge decreases, 10. increased flow of persistent springs, 11. drying of a spring and 13. stream gauges (hydroelectric power station). (B) Right. Vozmediano decreased spring flow and a few earthquakes felt at the site (intensity). Left: Hydrographs of the Vozmediano spring showing the post-seismic response to the 3 September 1961 Mw 5.8 (GHAP) Aguilar del Rio Alhama (or Magaña) earthquake. A. Agreda 2004 earthquakes, A(M). 3 September 1961 Mw 5.8 Aguilar del Río Alhama (or Magaña) earthquake, B1. Beraton 4 September 1987 Mw 3.0 earthquake, B2. Beraton 2 March 2013 Mw 3.0 earthquake, C. Cerbón 16 January 1906 (Mw 5), CA. Cueva de Agreda 24 November 2008 Mw 2.1 earthquake; FA. Cueva de Agreda 12 April 2011 Mw 4.4 earthquake; the FM Fuentes de Magaña 1 May 2012 Mw 2.5 earthquake shows the main springs in the area and those that have undergone post-seismic changes. 
A few of these faults are also related to the deep flows that circulate through them, generating thermal springs such as those of Arnedo and Fitero. Talamantes-Castilruiz is also a groundwater conductive fault related to the two largest non-thermal springs in the area: the Vozmediano spring (1100 L/s on average) and Ojos del Queiles (45 L/s); other important springs such as Añavieja (300 L/s) are close to the fault (Figure 1). This last spring drains a non-confined aquifer in carbonatic rocks. Vozmediano and the Ojos del Queiles springs drain the same aquifer, which is made up of about $1500 \mathrm{~m}$ of limestone and marl (Figure 2). The Vozmediano spring is one of the most abundant springs in Spain and its aquifer, in its free part, covers an area of about $150 \mathrm{~km}^{2}[15,16]$. The water rises under pressure as a spout up to $1.5 \mathrm{~m}$ during high water periods. This water is crystalline except during seismic events when the water instead turns cloudy and whitish in color due to the marl layers of the cover.

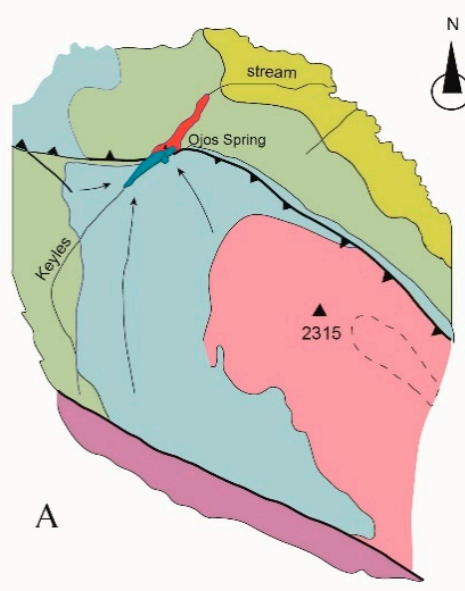

I

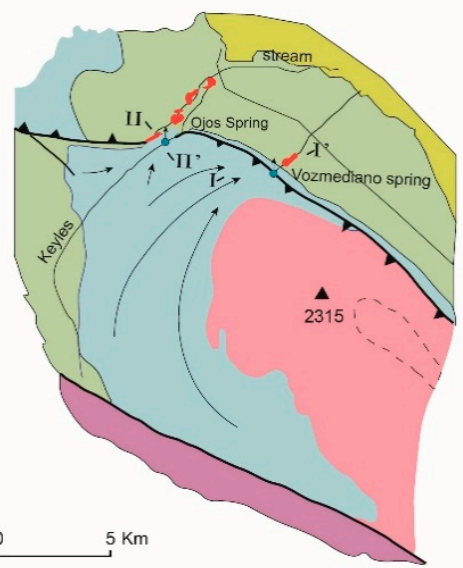

B

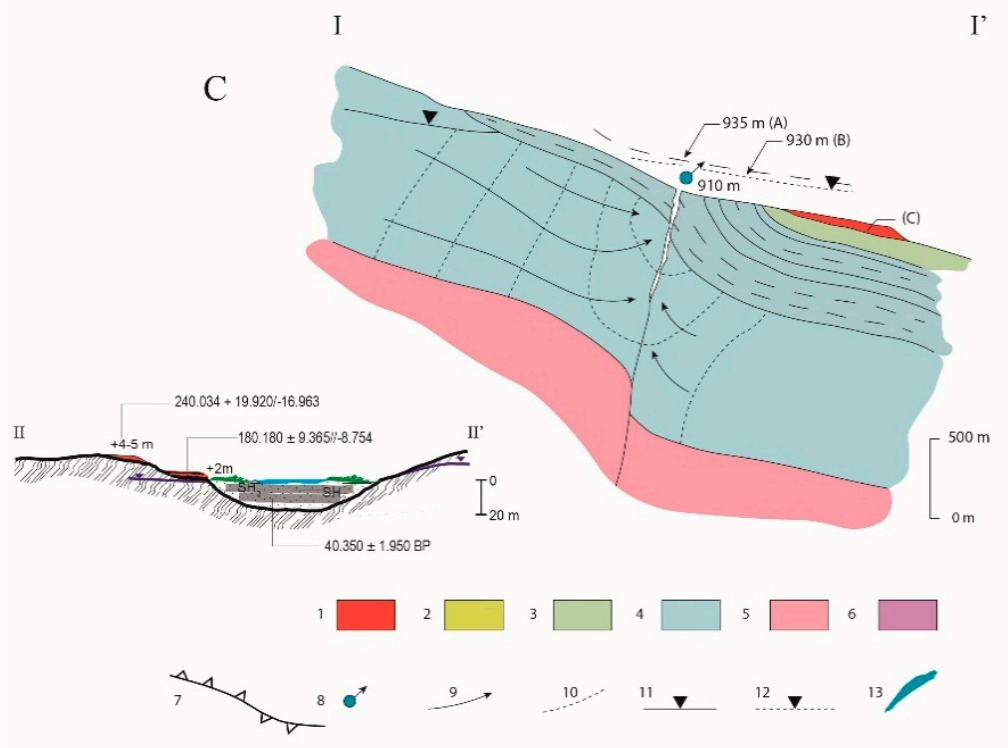

Figure 2. Origin of the Vozmediano spring. (A). Before the earthquake. Groundwater circulation during the Upper-Middle Pleistocene epoch to the Ojos del Queiles spring. (B). After the earthquake. Groundwater circulation to springs during the Upper Pleistocene, present time. (C). I-I' Schematic hydrogeological section of the Vozmediano spring site. II-II' Geological section of the Ojos del Queiles spring site and location of calcareous tuffs and lake deposits. Legend: 1 . calcareous tuffs, 2 . Neogene molasses, 3. Weald facies, 4. marine Jurassic, 5. Triassic (Buntsandstein facies), 6. Hercynian basement, 7. Talamantes-Castilruiz fault, 8. Springs, 9. groundwater flow lines, 10. equipotential lines, 11. water table, 12. piezometric level, 13. Ojillos del Queiles tuff barrier lagoon. 
In the northern sector of the fault within the impervious Weald facies there are small confined aquifers in the carbonatic layers interbedded with limolites, which are also discharged by confined fractures that give rise to emerging wells when the wells cut these aquifers. According to the data from [17], the specific storativity (S) in these wells is $10^{-6}$.

The flow of the Vozmediano spring was measured for a period of 20 years (1961-1981) showing great flow regularity and natural inertia. The flow does not usually drop below $600 \mathrm{~L} / \mathrm{s}$ and rarely exceeds $4000 \mathrm{~L} / \mathrm{s}[15,18]$. A single depletion curve can be identified in the hydrograph of this spring with a low slope ( $\alpha=0.003$ days $^{-1}$ ) and a hydrodynamic volume (or 'renewable reserve') of about $25 \mathrm{hm}^{3}$ at the beginning of the low water. It has a specific storativity of $10^{-2}$ in the free part and $10^{-4}$ in the semi-confined part of the aquifer [15].

\section{Methodology}

The following study methods were followed:

- The hydrogeological field investigations consisted of collecting information regarding hydrological alterations in 27 villages around the Talamantes-Castilruiz fault through interviews with people from the area, water supply entities, employees of power plants, etc. All of the springs that suffered some alterations were visited and inventoried.

- Analysis of the alterations observed in the hydrograph of the Vozmediano spring over a period of 20 years to identify responses to earthquakes.

- To determine ancient changes in the flow of groundwater due to earthquakes, a study was made on the calcareous tuffs of the springs. This cartographic study made it possible to locate the tufa outcrops associated with the Vozmediano and Ojos del Queiles springs. There is a distance of six kilometers between the two springs; in this space there are no other tuff deposits that indicate the existence of a paleo-spring. Five tuff samples from these springs were collected for dating via a U/Th imbalance series carried out at the Institute of Earth Sciences "Jaime Almera" of the CSIC using ICP-MS [19]. Preparation of the samples and radiometric dating using ${ }^{14} \mathrm{C}$ was carried out by the Instituto Rocasolano of the CSIC (Consejo Superior de Investigaciones Científicas).

\section{Results}

\subsection{Observations and Hydraulic Responses: Spring Flow Changes Along the Talamantes-Castilruiz Fault Zone} Caused by Multiple Earthquakes

Spring flow changes can be differentiated between earthquake-induced immediate responses and post-seismic flow changes. Figure 1 shows the main springs in the area and those that have undergone post-seismic changes. It can be observed that a persistent post-seismic decrease of the flow in springs and streams (although brief) has prevailed for both near and far earthquakes in the narrow area adjacent to the Talamantes-Castilruiz fault. This is more evident in aquifers with a significant degree of confinement such as Vozmediano and those within the Weald facies. The springs somewhat further from the area were only altered at the time of the earthquakes with drying that lasted for a few days at maximum.

Along the fault from northwest to southeast, small earthquakes such as that in Fuentes de Magaña on 1 May 2012 (Mw 2.5) decreased the flow of the sources for two days. Four springs of less than $10 \mathrm{~L} / \mathrm{min}$ associated with small confined fracture aquifers located in the epicentral zone also permanently dried up. There is hardly any information about the hydrogeological alterations from the Cerbón earthquake on 16 January 1906 (Mw 5) except for the appearance of a new sulfhydric spring that flowed for several months four kilometers southwest of the fault and then dried up forever.

During the Aguilar del Alhama (or Magaña) earthquake on 3 September 1961 (Mw 5.8), the flow of a small spring near the epicentral zone increased sixfold but the general trend was again towards a flow decrease in the springs near the fault, highlighting the area of Agreda and Vozmediano. In Agreda, fewer than $8 \mathrm{~L} / \mathrm{s}$ springs were dry for one day. 
The San Juan spring (Figure 1), which is associated with another regional fracture to the north, also dried up for a few hours. The Vozmediano spring, which had an average flow of $780 \mathrm{l} / \mathrm{s}$, dried up in a matter of $20 \mathrm{~min}$ one hour after the earthquake and two minutes after an aftershock. This spring was completely dry for nine hours, which led to a lack of electrical production in the power plants until the spring progressively recovered its previous flow. The spring water was then cloudy for $24 \mathrm{~h}$ (Figure 1). During the three small earthquakes in Agreda on 3 March 2004 (Mw 2.8), and 3 June 2004 (Mw 2.5), successive persistent drying over several days was observed in the small springs in Valverde de Agreda, located on a regional fault parallel to the north of the Talamantes-Castilruiz fault.

Other Variations in the Flow of the Vozmediano Spring Related to Earthquakes

As there have never been pumping wells in the Vozmediano aquifer within a radius of eight kilometers (and in the free zone of the aquifer with the least capacity to affect it), the abrupt declines and rapid recoveries in the hydrograph of the Vozmediano spring could only be due to seismic disturbances. A lack of recharge does not produce abrupt declines and immediate recoveries in this spring, which has been studied using a hydrograph and mathematical models of precipitation-runoff $[15,18]$. In addition, many of the observed declines coincide in time with earthquakes. During the Lisbon earthquake (1755), the water from Vozmediano spring was cloudy for several days [11]. Later, in the period of 1931-1981, according to the records of capacity and observations of the hydroelectric power plants downstream of the spring, the discharge in the Vozmediano spring decreased sharply and experienced episodes of turbidity 14 times although none of them dried completely except during the earthquake of 3 September 1961 (Mw 5.8).

On the other hand, sudden flow increases have never been observed in this spring. In the period of 1931-1981, flow data were only recorded from 1961 to 1981. In this 20-year period, eight flow decreases and turbidity increases were identified of which three coincided with distant earthquakes felt at this site with intensities greater than II on the Modified Mercalli Scale and two with nearby earthquakes (Figure 1). The rest of the turbidity events likely correspond to small unregistered earthquakes due to a lack of seismic networks in this area, which highlights the usefulness of the springs in capturing seismic signals. After 1981, there were also sudden flow drops but never increases. These drops were not documented, as noted by Evaristo Arlegui who was responsible for the FENSA (Fuerzas Eléctricas de Navarra Sociedad Anónima) Hydroelectric Power Plant for 40 years (Personal Communication). During this time, no pumping wells that could explain these abrupt flow decreases were drilled into the aquifer.

This spring always exhibits the same behavior when earthquakes occur: an abrupt post-seismic flow decrease (never increase) that lasts for several hours (no more than $24 \mathrm{~h}$ ), followed by a rapid and progressive increase until the pre-seismic flow is restored. During the flow recovery, the water comes out with white turbidity within one to a few days. This behavior was repeated with strong or medium earthquakes both in the distant field (such as that of Lisbon in $1755 \mathrm{M} \mathrm{8-9)}$ ) and in the near field (such as that of 3 September 1961 in Aguilar del Rio Alhama, Mw 5.8). The change in flow depends on the intensity felt at the site, regardless of the earthquake's magnitude and distance to the epicenter.

\subsection{The Calcareous Tuffs Associated with the Springs}

The study of the geomorphological evolution of the area [20], the U/Th dating of the calcareous tuffs deposited by the springs and analysis of ${ }^{14} \mathrm{C}$ in the associated lake sediments has allowed the reconstruction of the paleohydrogeology of the site.

The Ojos del Queiles spring area preserves the remains of dam-shaped tuff masses that gave rise to a lagoon during the Middle-Upper Pleistocene and early Holocene [21] epochs. In the Vozmediano spring, only a single tuff terrace was formed and extends one kilometer along the riverbed downstream from the spring.

Excluding two anomalous cases likely due to contamination, samples dated with U/Th offer a degree of reliability between acceptable and excellent. Table 1 shows the results for all of the samples. 
The tuffs of the Ojos del Queiles spring and associated lake deposits range between 240,000 BP and 40,000 BP (Table 1 and Figure 2). In Vozmediano, however, a tuff started to form around 19,159 BP (the sample was taken from the oldest part of the tufa). The sample of the ancient Agreda lagoon, dated by the radiocarbon method, provides an age corresponding to the warm interglacial stage MIS-3 of the Wurm glaciation. The other two tufa samples from the Ojos del Queiles indicate ages related to the stages of MIS-6 (cold period) and MIS7-8 of the Riss glaciation (the warm and cold stages, respectively, of the Riss glaciation). Vozmediano fully corresponds to the last ice age.

Table 1. Tuff samples dating from Ojos del Queiles (2012) and from the Vozmediano Springs (2019) by ${ }^{230} \mathrm{Th} /{ }^{234} \mathrm{U}$ and ${ }^{14} \mathrm{C}$.

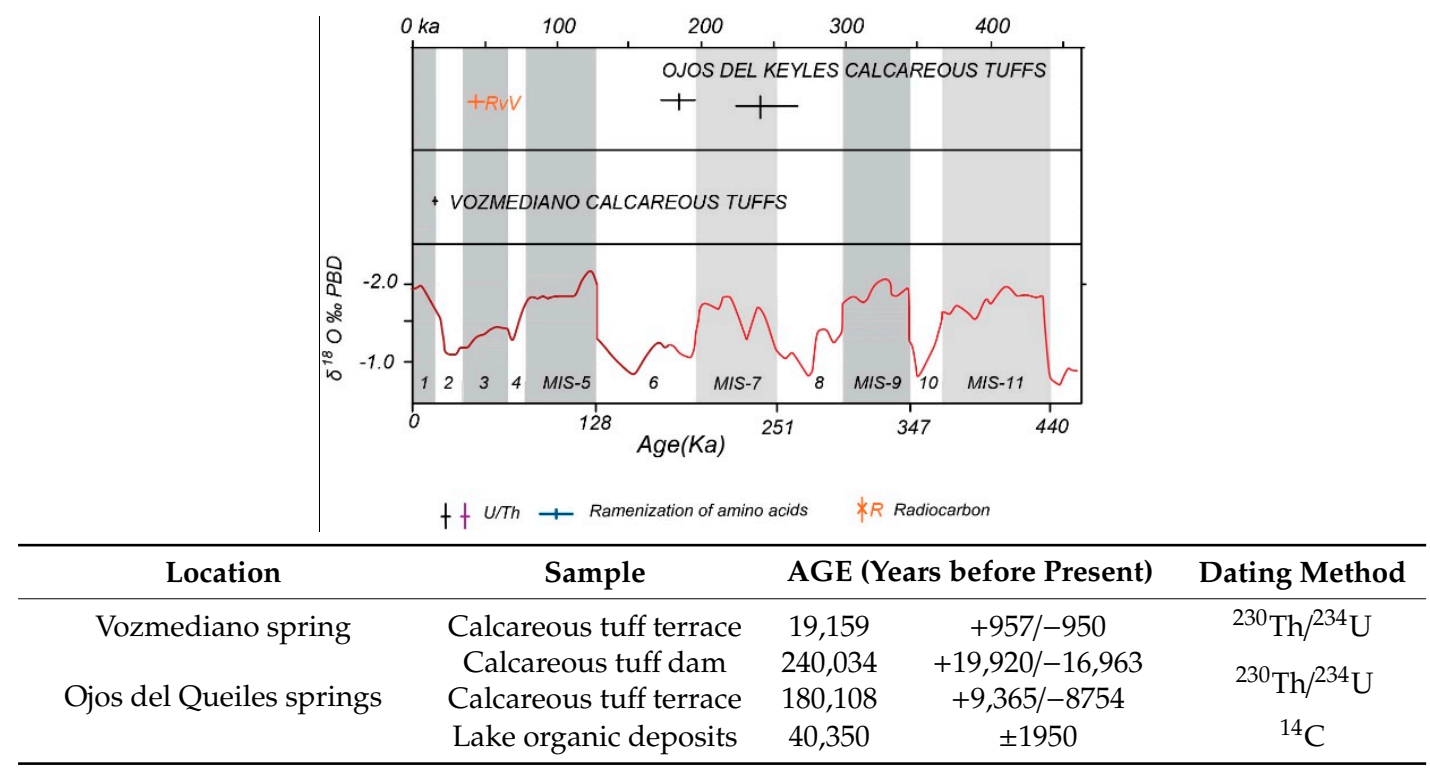

\section{Discussion}

\subsection{Discussion on Possible Mechanisms}

The changes produced by earthquakes in the springs associated with the Talamantes-Castilruiz fault usually have the same character and similar behaviors, featuring a decrease in their flow regardless of whether the earthquakes are large or small and near or far. The decrease in the flow of the springs near this fault may be caused by variations in the stress state around the fault, possibly due to a transient volumetric change in the rock mass that produces a decrease in pore pressure in the groundwater. However, the different magnitudes of the responses may be largely controlled by the different hydraulic properties of the aquifers along the fault. In free aquifers, the flow drops in Ojos del Queiles and Añavieja are less significant. Añavieja has a diffusivity (D) of $10^{-2}$ and an exhaustion coefficient $(\alpha)$ of 0.0016 days $^{-1}$ [17], less than the diffusivity of Vozmediano $\left(\alpha=0.003\right.$ days $\left.^{-1}\right)$. In contrast, the confined aquifers within the Weald facies are extremely sensitive, featuring the coseismic disappearance of small springs, which suggest an increase in permeability due to the generation of earthquake-induced micro-fracturing or the generation of new flow routes through other fractures.

The Vozmediano spring is also very sensitive to earthquakes. When moving from the free aquifer part (Ojos del Queiles springs, with $\mathrm{D}=10^{-2}$ ) to the semi-confined part (with $\mathrm{D}=6 \times 10^{-4}$ ) the diffusivity or sensitivity to an external seismic action increases by about 16 times while the transmissivity remains constant.

On the other hand, to visualize the hydraulic impact that the drying of the Vozmediano spring caused after the earthquake of 3 September 1961 in Aguilar del Rio Alhama (Mw 5.8), it was necessary for the piezometric level to fall by more than $20 \mathrm{~m}$ (Figure 2). The water not evacuated by the Vozmediano spring during drying was about $25,272 \mathrm{~m}^{3}$. If we consider a permanent storage coefficient 
of $S=6 \times 10^{-4}$, an almost instantaneous sump of water with $42.12 \mathrm{hm}^{3}$ of rock volume from the aquifer is needed to house this amount of water. This is only possible with a negative hydraulic pressure bump.

Most studies on changes in the flow of springs refer to changes observed during a single earthquake. For example, in Europe, the 1755 Lisbon earthquake changed the location of at least 15 springs and the thermal springs of Carsbar (Germany) appeared [11]. However, a few studies refer to the behavior of specific faults subjected to multiple earthquakes [7] although there are not enough examples to draw clear conclusions and compare those examples with our case. It seems, however, that some of these studies indicate the same hydrogeological behavior of faults in the face of local and distant earthquakes. Manga et al. [13] observed an increase in the streamflow responses in the Sespe Creek basin, regardless of the contractive or expansive nature of the earthquake-induced static strain. Likewise, in the Garni fault (Armenia), the streamflow responses followed the same pattern with variations in the spring discharges controlled by changes in the stress state near the fault. The state of stress variations is a consequence of alternations in stick-slip movements and elastic strain in the fault and creeping further away from the fault [22].

From a practical point of view, the hydrological changes of drying and temporary water turbidity can occasionally affect the water supply intended for people, livestock and fish farms for a few hours to days. These changes also affected the production of electricity for a few hours in the Keyles electric power plant in Vozmediano. More worrying is the irrecoverable loss of stream flows that have also occurred. In any case, these results should be taken into account when evaluating the seismic risk of the area.

\subsection{Modification of the Underground Flow due to the Effects of an Earthquake: The New Vozmediano Spring}

According to the results of dating the calcareous tuffs, we verified that the Vozmediano spring is recent as it began operating 19,159 years ago. Before and during the middle Pleistocene and part of the upper Pleistocene epochs, all of the groundwater flow from the aquifer was directed towards the Ojos de Agreda springs. At that time, the encrusting waters of a large spring created a single mass of tuff that closed the valley and formed a lagoon (Figure 2A). The idea of a spring location change, proven in this work, was first proposed as a possibility in [21]. However, the lowering of the relief on the eastern side due to rising erosion at the head of the ravines of the Queiles River has thinned the impermeable and confining cover of the aquifer from the Middle Pleistocene to the present day [23] and shortened the stretch of the fault cutting this cover. It is estimated that from the beginning of the Quaternary to the present day, the thalweg of the Queiles River dropped by about $25 \mathrm{~m}$ at the site of Vozmediano (Figure 2C). This did not happen with the Queiles River because the tobaceous barrier stopped the rising erosion. The rivers of the Ebro basin (Keyles and Rio de Vozmediano) partially eroded the masses of tuffs and the outcrops remain the same today, as represented in Figure 2B. This same erosion partially dismantled the Neogene cover, whose contact with the Mesozoic substrate receded towards the northeast (Figure 2B). The increase in the water level was likely due to greater recharge during glaciation, which would have increased the pressure in the confined area of the aquifer on the weaker cover crossed by the fault. However, the ultimate triggering cause was likely seismic activity, which definitively changed the main discharge point of the aquifer, moving the water exit through the same fault plane to the lowest point of least resistance. The discharge point thus changed from a free zone to a semi-confined zone.

The mechanism remains unknown (for example, overpressure and rupture of the aquifer) but the change in the spring location was likely rapid, judging by the sudden appearance of a significant mass of tuffs in Vozmediano. Having been established and relocated in the main spring in Vozmediano, the Ojos del Queiles spring remained as a secondary and residual spring, serving as a trop-plein in high waters when the maximum drainage limit is exceeded through the Vozmediano spring conduit. The same could happen with the artesian spring of San Juan (200 L/s of average flow) (Figure 1), which is located in a seismic fault belonging to the Cameros thrust front that crosses the Neogene cover. The results obtained in this paleohydrogeological investigation thus support the existence and 
importance of the Talamantes-Castilruiz fault, which is not always well recognized and whose layout, given in [24], is the layout used in Figures 1 and 2 (although we extended the layout to the northwest).

Once the outlet for the Vozmediano spring was established, apart from an increase in permeability due to a dissolution of calcareous materials, clays were possibly washed from the marl layers of the cover through the fault conduit due to the effects of earthquakes. In this spring, the seismic effect produces a vast over-pumping that lasts up to $24 \mathrm{~h}$ and then continues with a very rapid recovery, causing a flow-reflux effect and consequent cleaning of the duct and its environment as commonly done in the development techniques for groundwater catchment wells. The number of one-day turbidity events over the last 50 years was 15 , which, considering geological time, is equivalent to 3000 days (more than eight years) of the evacuation of fine materials during the Holocene epoch (10,000 years), with a consequent increase in permeability.

\section{Conclusions}

Although the study area possesses moderate seismicity, the presence of varied hydrogeology as well as the existence of deposits generated by springs susceptible to dating allowed us to identify the importance of the changes induced by earthquakes in the flows of these springs. This hydrogeology also made it possible to determine the significant displacement of the location of the large Vozmediano spring (1100 L/s) along the Talamantes-Castilruiz fault during the Upper Pleistocene epoch.

The observations made in this study highlight the seismic role of the aforementioned fault where the sensitivity of the responses caused by earthquakes to the flow of the springs located along the fault increases with the degree of the confinement of the aquifers.

Faced with near and far earthquakes of different magnitudes, these springs always react by decreasing their flow. These flow changes are documented in more detail in the Vozmediano spring where sudden and short drying periods occur with increased turbidity.

The results of this work contribute to a better understanding of the seismic risk in the area.

Author Contributions: E.S. surveyed the previous studies, provided the original idea of the study and finalized the manuscript. I.M.P., supervision and project administration. J.I.E., review and editing. J.S.d.O., field research. All authors have read and agreed to the published version of the manuscript.

Funding: This research was supported by the National Research Programs of Spain (PID2019-106887GB-C3), Ministry of Science and Innovation. Part of the dating of this study was financed by the Research Groups of the Polytechnic University of Madrid in 2019 (VAGI18ESP).

Acknowledgments: We would like to thank the editors and reviewers for their comments and suggestions that have led to improvements in the manuscript.

Conflicts of Interest: The funders had no role in the design of the study; in the collection, analyses or interpretation of data; in the writing of the manuscript or in the decision to publish the results.

\section{References}

1. Elkhoury, J.E.; Brodsky, E.E.; Agnew, D.C. Seismic waves increase permeability. Nature 2006, 411, 1135-1138. [CrossRef]

2. Itaba, S.; Koizumi, N. Earthquake-related changes in groundwater levels at the Dogo hot spring, Japan. Pure Appl. Geophys. 2007, 164, 2397-2410. [CrossRef]

3. Manga, M. Origin of postseismic streamflow changes inferred from baseflow recession and magnitude-distance relation. Geophys. Res. Lett. 2001, 28, 2133-2136. [CrossRef]

4. Roeloffs, E.A. Persistent water level changes in a well near Parkfield, California, due to local and distant earthquakes. J. Geophys. Res. 1998, 103, 869-889. [CrossRef]

5. Sato, T.; Sakai, R.; Furuya, K.; Kodama, T. Coseismic spring flow changes associated with the 1995 Kobe earthquake. Geophys. Res. Lett. 2000, 27, 1219-1222. [CrossRef]

6. Wang, C.Y.; Chia, Y. Mechanism of water level changes during earthquakes: Near field versus intermediate field. Geophys. Res. Lett. 2008, 35, L12402. [CrossRef]

7. Wang, C.Y.; Manga, M. Earthquakes and Water; Springer: Berlin/Heidelberg, Germany, 2010. [CrossRef] 
8. Shi, Z.; Wang, G. Aquifers switched from confined to semiconfined by earthquakes. Geophys. Res. Lett. 2016, 43, 11-166. [CrossRef]

9. Manga, M.; Rowland, J.C. Response of alum rock springs to the October 30, 2007 earthquake and implication for increased discharge after earthquakes. Geofluids 2009, 9, 237-250. [CrossRef]

10. Muir-Wood, R.; King, G.C.P. Hydrological signatures of earthquake strain. J. Geophys. Res. 1993, 98, 22035-22068. [CrossRef]

11. Sanz de Ojeda, A.; Alhama, I.; Sanz, E. Aquifer Sensitivity to Earthquakes: The 1755 Lisbon Earthquake. J. Geophys. Res. Solid Earth 2019, 124, 8844-8866. [CrossRef]

12. Charmoille, A.; Fabbri, O.; Mudry, J.; Guglielmi, Y.; Bertrand, C. Post-seismic permeability change in a shallow fractured aquifer following a M-L 5.1 earthquake (Fourbanne karst aquifer, Jura outermost thrust unit, eastern France). Geophys. Res. Lett. 2005, 32, L18406. [CrossRef]

13. Manga, M.; Brodsky, E.E.; Boone, M. Response of streamflow to multiple earthquakes and implications for the origin of postseismic discharge changes. Geophys. Res. Lett. 2003, 30, 1214. [CrossRef]

14. Sanz-Pérez, E.; Menéndez-Pidal, I.; Galindo, R.; López-Querol, S.; Pascual, C. Historical earthquake parameters by geological and seismic site analysis: The 1908 Cerbón earthquake (Spain). Bull. Eng. Geol. Environ. 2016, 75, 1251-1271. [CrossRef]

15. Sanz-Pérez, E. El Karst del sur y Oeste del Moncayo. Ph.D. Thesis, Universidad Complutense de Madrid, Madrid, Spain, 1981. Unpublished.

16. Sanz-Pérez, E. Le Karst du Sud et de l’Ouest du Moncayo (Cordillera Ibérica). Soria, Espagne. Karstologia 1986, 7, 31-36. [CrossRef]

17. SGOP. Estudio Hidrogeologico de la Provincia de Soria; Internal Repport; Servicio Geológico de Obras Públicas: Madrid, Spain, 1980.

18. Sanz-Pérez, E. Application and simplification of the SIMERO model for the Vozmediano Spring (Spain). Hydrol. Sci. J. 1996, 41, 763-779. [CrossRef]

19. Hellstrom, J. Rapid and accurate U/Th dating using parallel ion-counting multi-collector ICP-MS. J. Anal. At. Spectrom. 2003, 18, 1346-1351. [CrossRef]

20. Pellicer, F.; Echevarria, M.T. El sistema de terrazas y glacis en el piedemonte septentrional del macizo del Moncayo. In Geografía Física de Aragón. Aspectos Generales y Temáticos; Peña, J.L., Longares, L.A., Sánchez, M., Eds.; Universidad de Zaragoza e Institución Fernando el Católico: Zaragoza, Spain, 2004; pp. 163-171.

21. Sanz-Pérez, E.; Pascual, C.; de Ojeda, L.S.; Menéndez-Pidal, I. La antigua laguna de Agreda. Celtiberia 2015, 109, 177-191.

22. Léonardi, V.; Arthaud, F.; Tovmassian, A.; Karakhanian, A. Tectonic and seismic conditions for changes in spring discharge along the Garni right lateral strike slip fault (Armenian Upland). Geodin. Acta 1998, 11, 85-103. [CrossRef]

23. García-Gil, A.; Sánchez-Navarro, J.A.; Pérez-García, A.; Vázquez-Suñe, E.; Matéo, J. Cuantificación del flujo subterráneo en la vertiente suroccidental del Macizo del Moncayo, España. Geogaceta 2013, 54, 107-110.

24. Gil Imaz, A. La Estructura de la Sierra de Cameros: Deformación Dúctil y su Significado a Escala Cortical; Centro de Estudios Riojanos: Logroño, España, 2001; 305p, ISBN 84-95747-09-X.

Publisher's Note: MDPI stays neutral with regard to jurisdictional claims in published maps and institutional affiliations.

(C) 2020 by the authors. Licensee MDPI, Basel, Switzerland. This article is an open access article distributed under the terms and conditions of the Creative Commons Attribution (CC BY) license (http://creativecommons.org/licenses/by/4.0/). 